\title{
Cytological Studies on Yeast Cells with Special Reference to the Budding Process ${ }^{11}$
}

\author{
By
}

H. W. Beams, L. W. Zell, and Norman M. Sulkin

Department of Zoology, State University of Iowa

Receized May' 28, 1940

The method of nuclear division in budding yeast cells has long been a subject of discussion and controversy. Wager (1898), Guilliermond $(1904 ; 1910 ; 1919)$, Wager and Peniston (1910) and others have described a typical amitotic type of division, while Swellengrebel (1905), Fuhrmann (1906) and Kater (1927) describe the nuclear division as a mitotic process or some variation of it. The smallness of the yeast cell, together with its obscuring cellular inclusicns, makes cytological studies extremely difficult and interpretations in many instances questionable.

We have studied the division process of budding yeast by certain of the methods employed by previous investigators and, in addition, have utilized the Feulgen technique in an effort to throw further light on this problem. Accordingly, it is the purpose of this paper to report the results of our studies in the event that they may add to the general knowledge of this subject.

No effort has been made here to review all the literature relating to the numerous studies on the budding process of yeast, since gcod summaries of the literature have been given by Wager (1898), Wager and Peniston (1910), Guilliermond $(1910 ; 1919)$ and Kater (1940).

\section{Materials and Methods}

The material used in these experiments was a pure strain of Saccharomyces cerevisiae.") The stock was kept in a sterilized flask in a refrigerator at $5^{\circ} \mathrm{C}$. and when taken from the refrigerator was. practically in a non-budding condition.

A small portion of the compressed yeast (a piece approximately the size of a pea) was placed in a test tube containing about $20 \mathrm{cc}$. of Williams' media (Williams, 1920) and then placed in an incubator

1) Aided by grant from the Rockefeller Foundation for work on Cellular Biology.

2) It is indeed a pleasure to express here our indebtedness to the authorities of the Anheuser-Busch Co. for their kindness in supplying us with the yeast. 
at $30^{\circ} \mathrm{C}$. until active budding occurred. Permanent slide preparations were made by coating a clean slide with egg albumin, placing on it a few drops of a concentration of the cells obtained by centrifuging with an electric centrifuge, and evaporating the excess media. However, the slides were never allowed to become completely dry before they were fixed. The following fixatives were used: Bouin's, Schaudinn's, and saturated mercuric chloride in $2 \%$ acetic acid. In most instances cells fixed in Bouin's solution were stained in Heidenhain's haematoxylin and those fixed in Schaudinn's solution were stained in $5 \%$ methylene blue. The Feulgen reaction was employed following mercuric chloride-acetic acid and Schaudinn's fixation. The Feulgen reaction and technique used are those described by Margolena (1932) and Ludford (1928).

The yeast cells were also cultured in a mixture containing $2 \%$ colchicine in Williams' media. They were subsequently fixed and stained in the same manner as the untreated cells mentioned above.

\section{Description}

\section{The living unstained cells.}

A study of the living unstained yeast cell, even under the oil immersion lens, reveals comparatively little of its internal structure (figs. 1,2). The cells of Saccharomyces cerevisice are round to slightly oval in shape and vary in size from 5 to 10 micra. The mother cell is frequently somewhat eiongated during the process of budding (fig. 2). The cytoplasm is translucent and usually contains one (occasionally several) large vacuoles, one or more smaller vacuoles probably containing glycogen (Wager and Peniston, 1910), and a varying number of small highly refractive granules (figs. 1, 2). The granules exhibit Brownian movement and stain intensely with methylene blue. They are in all probability the volutin granules described by Wager and Peniston (1910), Guilliermond (1919), and others. Studies of the living cells reveal no structure that we could unquestionably interpret as the nucleus. Likewise, studies of the budding cells disclosed no clue as to the mode of nuclear division during that process. For a more complete discussion and description of the normal yeast cell see Wager (1898) and Guilliermond (1919).

\section{Budding cells of stained preparations.}

Since studies of the living cells reveal very little in regard to their nuclear division and other intricate cellular phenomena, it was necessary to employ various staining techniques. In addition, it was found desirable to use material from fresh cultures, since the accumu- 


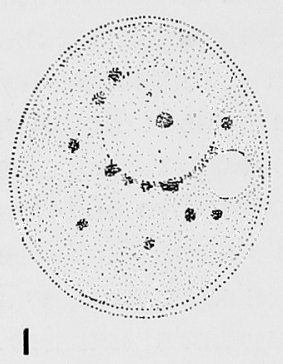

I

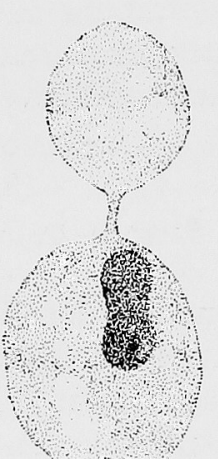

5

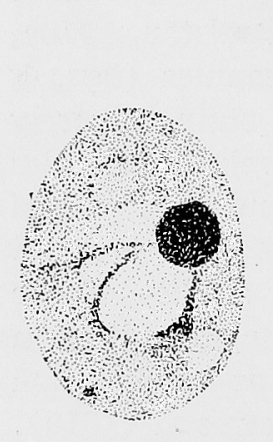

9
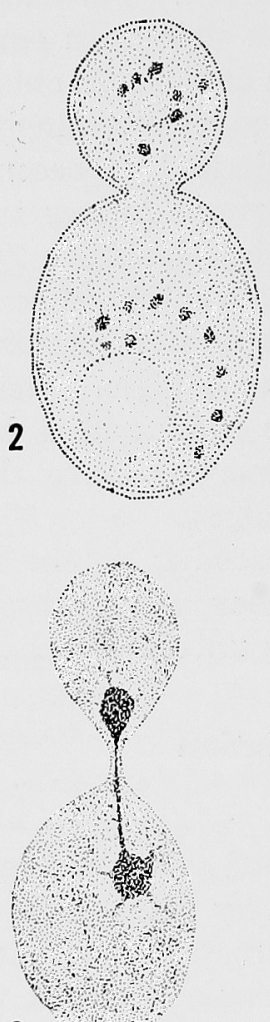

6

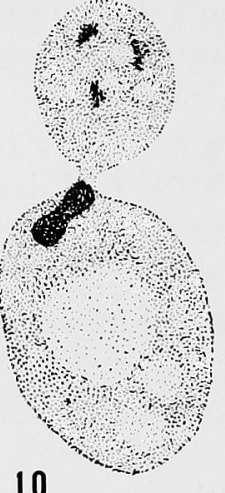

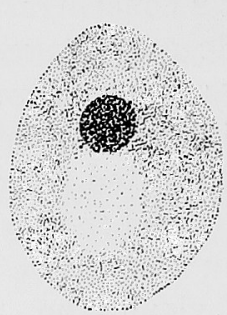

3
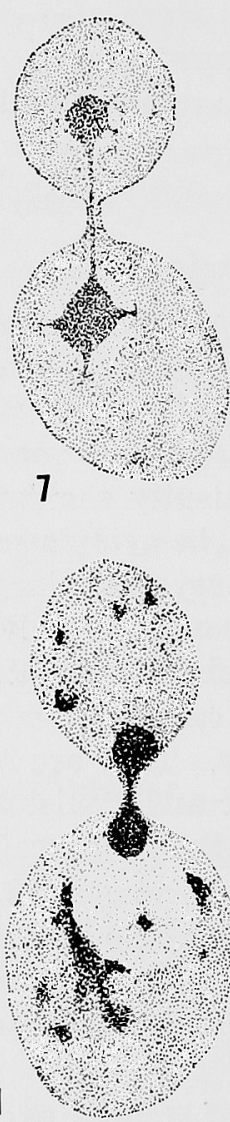

8

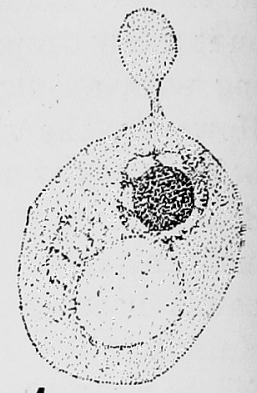

4
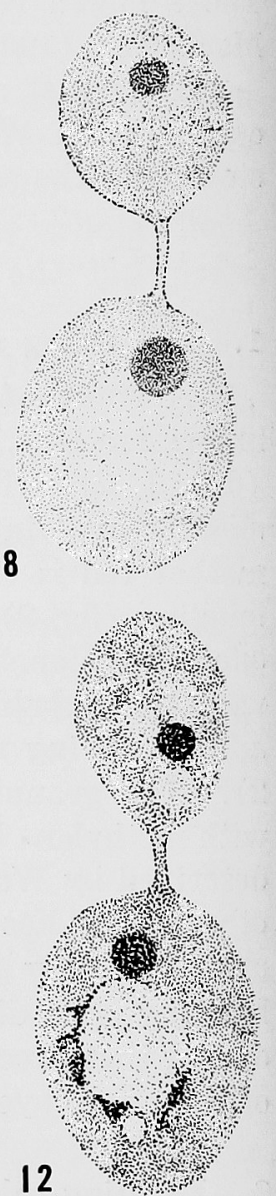

Figs. 1-12. 1. Living, unstained cell, showing thin cell wall, refractive granules, large central vacuole containing granules, small glycogen vacuole, and translucent cytoplasm. 2. Living, unstained cell with well developed bud. 3. Normal cell, fixed in $2 \%$ acetic acid saturated with mercuric chloride and stained by the Feulgen technique, showing nucleus, and large vacule. 4-8. Cells in the process of budding. Fixed in saturated mercuric chloride in $2 \%$ acetic acid, stained by the Feulgen 
lation of glycogen and granules with a high affinity for the commonly used nuclear stains in old cultures tends to obscure the nucleus and makes interpretation of nuclear division very difficult. Different structures have been described as the nucleus by those who have worked on yeast and, because of this fact, the Feulgen reaction which is considered relatively specific for the nuclear chromatin of yeast by Margolena (1932) was employed. Cells stained according to the Feulgen technique consistently revealed a definite rounded or irregular shaped body in the cell which is pink or light red in color (fig. 3). Heidenhain's haematoxylin preparations demonstrated a comparable structure which here appears as a dark body against a light background (fig. 9). This body we have interpreted as the nucleus for the following reasons: (1) a similar structure stained in Heidenhain's haematoxylin has been described as the nucleus by certain other workers (Guilliermond, 1919); (2) Margolena (1932) has found the Feulgen reaction to stain the nucleus of yeast cells although Feulgen (1924) and Westbrook (1930) report a negative reaction for the nucleus of yeast and bacteria (cf. Margclena, 1932) ; (3) no other structure was found which could possibly be interpreted as a nucleus apart from that stained by the Feulgen reaction; and (4) this body (nucleus) undergoes a typical amitotic division during the budding process.

In many cells that were stained in Heidenhain's haematoxylin the nucleus seems to be associated with a vacuole-like structure, and it is difficult to determine whether this appearance is due to shrinkage or to the presence of an actual vacuole (figs. 4, 6 and 7). All the fixed cells show some shrinkage.

The history of the nucleus during the budding process is illustrated in figures $4,5,6,7,8,10,11$, and 12 . Here it will be observed that the division of the nucleus constitutes a typical amitotic process, comparable in many respects to the conditions described by Guilliermond $(1904 ; 1919)$, and others. In addition to the above mentioned cytological evidence, experiments with colchicine, which is known to inhibit mitosis (Ludford, 1936; Beams and King, 1938; and others) revealed that the budding process of the yeast cells was not noticeably affected by its action. A cytological study of the cells treated with colchicine shows a typical amitotic division of the nucleus. Furthermore, it has been shown by Richards (1938) that colchicine actually stimulates budding rather than inhibits it.

technique, showing nucleus in various stag:s of division. 9. Normal cell, fixed in Bouin's solution, stained in Heidenhain's haematoxylin, sbowing nucleus, one large vacuole, three small glycogen vacuoles, and dark staining granules. 10-12. Normal cells in the process of budding. Fixed in Bouin's solution stained in Heidenhain's haematoxylin. 


\section{Discussion}

As previously pointed out, the size of the yeast cells, together with the difficulties in interpreting their stained cellular contents, has made the problem of nuclear division a subject of considerable controversy. Wager (1898), Wager and Peniston (1910), Guilliermond (1919), and Kater (1927) have all described the nucleus and nuclear division. The fact that no stain specific for nuclear materials was available probably accounts for a part of the difference in interpretations given by the various workers on yeast. Inasmuch as the Feulgen reaction has been applied by Margolena (1932) to the nucleus of certain botanical material with positive results, it seemed worthy of consideration in any attempted solution of the problem of nuclear division in yeast. Since we too have found that the Feulgen method stains the nuclei of yeast cells, we agree with Margolena (1932) who, while commenting upon the reaction of the Feulgen method with yeast nuclei, states: "At present it suffices to say that either the yeast cells contain some of the same kind of chromatin as do nuclei of other organisms, or else Feulgen's reaction is not so specific for one particular kind of nucleic acid as claimed by its author." The former suggestion now seems correct since Hillary (1939) states that Feulgen, Behrens, and Mahdihassan have developed a method of separating a pure plant nucleic acid from plant nuclei. "Thus plant and animal nucleic acids are one and the same thing and the nucleal reaction works equally well with both" (Hillary, 1939).

The fact that one group of workers (Guilliermond, 1904; 1910; 1919; Wager and Peniston, 1910) believes that the division of the nucleus during the budding process is amitotic while another group (Swellengrebel, 1905; Fuhrmann, 1906; Kater, 1927) is of the opinion that the division is mitotic necessitates consideration of the division phenomena. The discovery of mitosis and the recognition of its general occurrence in the plant and animal kingdoms led many workers to doubt that amitosis ever occurs as a normal process. Some authors were of the opinion it occurred only in pathological and degenerating cells. However, in the words of Conklin (1917), "The number of cases in which nuclear constriction is known to occur regularly in certain tissue cells is too great to warrant the belief that it is always a pathological phenomenon." Nevertheless, it seems that some writers were ready to reject amitosis and set up a defense in favor of mitotic division merely to be in harmony with modern genetic reasoning. The work of Kater (1927) seems to place itself in this category. That he was not able to establish conclusively 
the process of mitosis in the budding yeast cells was evident when he said, "The above account leaves two points without adequate solution, namely the transformation of the nucleus into chromosomes and the migration of chromosomes through the isthmus." Several recent papers have appeared which show that amitosis occurs as a normal process in the division of the nucleus and cells of certain tissues of higher animals (see for instance Bast, 1921). Furthermore, the work of Richards (1938) which we have confirmed here, namely that colchicine does not inhibit the budding process in yeast, seems to lend strong support to the view that the budding mechanism does not take place by means of a mitotic process. This is substantiated by the fact that colchicine readily destroys the spindle and blocks the division of the cytoplasm in both plant and animal cells where mitosis is normally known to occur. That the colchicine actually enters the yeast cells was established by Richards (1938) who found that it stimulated the growth process rather than inhibited it. In addition, King and Beams (1940) have found that fission of certain protozca occurs in strong colchicine solutions as also does ameboid movement. In these protozoa too no apparent evidence of a mitotic spindle has been found.

Accordingly, for the present at least, it seems that the majority of the evidence supports the view that the division process in budding yeast is amitotic and until better methods are developed for studying this process we believe that it should be considered as such.

\section{Conclusions}

1. The cells of the yeast, Saccharomyces cerevisicie, possess a definite compact nucleus which gives a positive reaction with the Feulgen method.

2. All cytological evidence shows that the division of the yeast cells during the budding process is amitotic.

3. Colchicine in strong concentrations does not inhibit the budding process in yeast. This is in striking contrast to its action upon other plant and animal cells which are known to divide by mitosis.

\section{Bibliography}

Ba t, T.H. 1921 Studies on the structure and multiplication of bone cells facilitated by a new technique. Am. Jour. Anat., 29: 139-157.

Beams, H. W. and R. L. King 1938 An experimental study on mitosis in the somatic cells of wheat. Biol. Bull., 75: 189207.

Conklin, E. G. 1917 Mitosis and amitosis. Biol. Bull., 33: 396-416.

Fuhrmann, F. 1906 Der feinere Bau der Saccharomycetenzelle. Centbl. f. Bakt., $16: 629$

Guilliermond, A. 1904 Sur la noyau de la levure. Ann. Mycol., 2 : 184-189. 
Guilliermond, A. 1910 Remarques critiques sur differentes publications parues recement sur la cytologie des levures et quelques observations nouvelles sur la structure de ces champignons. Centralbl. f. Bakt., 26: 576-589.

- 1919 The yeasts (translated by F. W. Tanner). John Wiley and Sons.

Hillary, B. B. 1939 Use of the Feulgen reaction in cytology. I. Effect of fixatives on the reaction. Bot. Gaz., $101: 276-300$.

Kater, J. McA. 1927 Cytology of Sacharomyces cerevisiae with especial reference to the nuclear division. Biol. Bull., 52: 436-446.

Kater, J. McA. 1940 Amitosis. Bot. Rev., 6 : 164-180.

King, R. L. and H. W. Beams 1940 A comparison of the effects of colchicine on division in protozoa and certain other cells. Jour. Cell. and Comp. Physiol., 15: $252-253$

Ludford, R. J. 1928 Studies in the microchemistry of the cell. I. The chromatin content of normal and malignant cells, as demonstrated by Feulgen's "Nuclealreaktion." Proc. Roy. Soc. B., 102 : 397-406.

- 1936 The action of toxic substances upon the division of normal and malignant cells in vitro and in vivo. Arch. exper. Zellforschg., 18 : 411-441.

Margolena, L. A. 1932 Feulgen's and some of its applications for botanical material. Stain. Tech., $7: 9-16$.

Richards, O. W. 1938 Colchicine stimulation of yeast growth fails to reveal mitosis. Jour. Bact., 36 : 187-195.

Swellengrebel, M. 1905 Sur la division nucléaire de la levure pressée. Ann. Inst. Pasteur, 19: 503-514.

Wager, H. 1898 The nucleus of the yeast plant. Ann. Bot., 12 : 499-544.

- and A. Peniston 1910 Cytological observations on the yeast plant. Ann. Bot., 24 : 45-84.

Williams, R. J. 1920 A quantitative method for determination of vitamins. Jour. Biol. Chem., 42: 259-268. 